\title{
International Business Strategy in Selling Korean Pop Music: A Case Study of SM Entertainment
}

\author{
Annisa Pratamasari \\ Departemen Hubungan Internasional Universitas Airlangga
}

\begin{abstract}
In this paper, I argue that some entertainment companies of South Korea offer a distinctive business strategy in this globalized world; thus, they can widen their market share, increase profits, and sharpen their competitive edge. SM Entertainment,which is one of the Hallyu Wave pioneers in music industry, has showed its distinct way to succeed in the currently saturated market of idol groups in South Korea. Choosing Hallyu Wave from international business perspective as the main topic of this writing was due to its increasing importance in music industry and its growing influence in South Korean government policies. Therefore, I shall descriptively address the strategies formulated by SM Entertainment to compete in the domestic and international music industry from its way to groom their idol groups to its way to 'sell' them.This paper offers some business strategies of SM Entertainment of which some other companies could learn from; namely the distinct traineeship system, successful B2C strategy, and profitable B2B cooperation.
\end{abstract}

Keywords: Hallyu Wave, SM Entertainment, international business, business strategy

Pada artikel ini, saya berargumen bahwa sebagian perusahaan hiburan di Korea Selatan menawarkan suatu strategi bisnis yang unik di dunia yang telah mengglobal ini; oleh karena itu, mereka dapat memperluas pangsa pasar, meningkatkan laba, dan mengasah ketajaman kompetensi mereka. SM Entertainment, sebagai salah satu dari pioner Hallyu Wave, telah menunjukkan strategi uniknya untuk mereguk sukses dalam pasar grup idola yang semakin sesak di Korea Selatan. Pemilihan Hallyu Wave dari perspektif bisnis internasional untuk topik utama tulisan ini disebabkan oleh peningkatan derajat kepentingan Hallyu dalam industri musik dan pertumbuhan pengaruhnya dalam kebijakan-kebijakan pemerintah Korea Selatan. Oleh karena itu, saya akan menjabarkan secara deskriptif strategistrategi yang diformulasikan oleh SM Entertainment untuk berkompetisi dalam industri musik domestik dan internasional, mulai dari cara 'membesarkan' grup idola mereka hingga cara 'menjual' mereka. Tulisan ini membahas tentang sebagian strategi bisnis SM Entertainment yang dapat dijadikan pelajaran oleh perusahaan lain; misalnya sistem traineeship yang unik, strategi B2C yang sukses, dan kerjasama B2B yang menguntungkan.

Kata kunci: Hallyu Wave, SM Entertainment, bisnis internasional, strategi bisnis 


\section{Introduction}

Hallyu Wave is also known as "Korean ${ }^{1}$ Wave". It refers to the sudden increase in popularity of South Korean culture around the world in the last ten years, largely due to the Korean entertainment industry and the popularity of K-drama and K-pop (Lee 2011; Ravina 2010). For Kdrama, the first wave started with an extremely popular k-drama called "Winter Sonata" in which Bae Yong Jun starred in it. Until now, the Nami Island, where this drama was filmed, is still one of the main tourist attractions in Korea. While in K-pop, or Korean pop, the first wave started when SM Entertainment acted as a pioneer by producing a boygroup called H.O.T in 1996. Since then, there has been hundreds of Korean boybands and girlbands are produced by numerous entertainment companies. Their worldwide popularity has increased tremendously for these last few years, especially with the globalization and the advancement of internet. Furthermore, South Korean government offers its support by using K-pop images to generate its nation revenue from several sectors, such as tourism (Lee, et al. 2008); as well as to promote South Korean culture overseas as a part of its diplomacy mission to enhance its national image and soft power (Jang\& Park 2012; Lee 2013 in Negus 2015). The government even established KOCCA (Korea Creative Content Agency) in 2009 with the purposes to support and export cultural and content industry (Korea Creative Content Agency 2014).

Even though there is a language challenge (for not being sung in English like other popular music), the music has also received tremendous international attention since the late 1990 s by global audiences through various online platforms; such as social medias, fan blogs, usergenerated content website, and peer-to-peer (P2P) sharing website (Jung \& Shim 2014; Shim \& Noh 2012). Moreover, the topics related to K-pop and its artists have been circulated widely on the internet, especially through the trending topics of Twitter or the views on Youtube videos (Jung \& Shim 2014). For example, 'Gentleman' MV by PSY who created a craze with his 'Gangnam Style' gained more than 22 millionviews in the first day after release, setting a record on a mostviewed video at the first day (Jpop Asia 2013a). Meanwhile, views for Kpop videos reached 2.3 billion on YouTube in 235 countries in 2011 (Seo 2013). Based on the Figure 1 below, Thailand, US, Vietnam and Japan have more views on K-Pop video than Korea itself. K-Pop videos also got millions of views in Europe, South Africa, and Middle East who are culturally and geographically far from what Korea has and K-Pop presented on their video. Those Youtube views depict the global-ness of Korean pop music nowadays.

${ }^{1}$ As there are two Koreas politically, to avoid ambiguity, I shall explain that 'Korean' in this paper is used to illustrate 'South Korea'. Both terms are used interchangeably. 


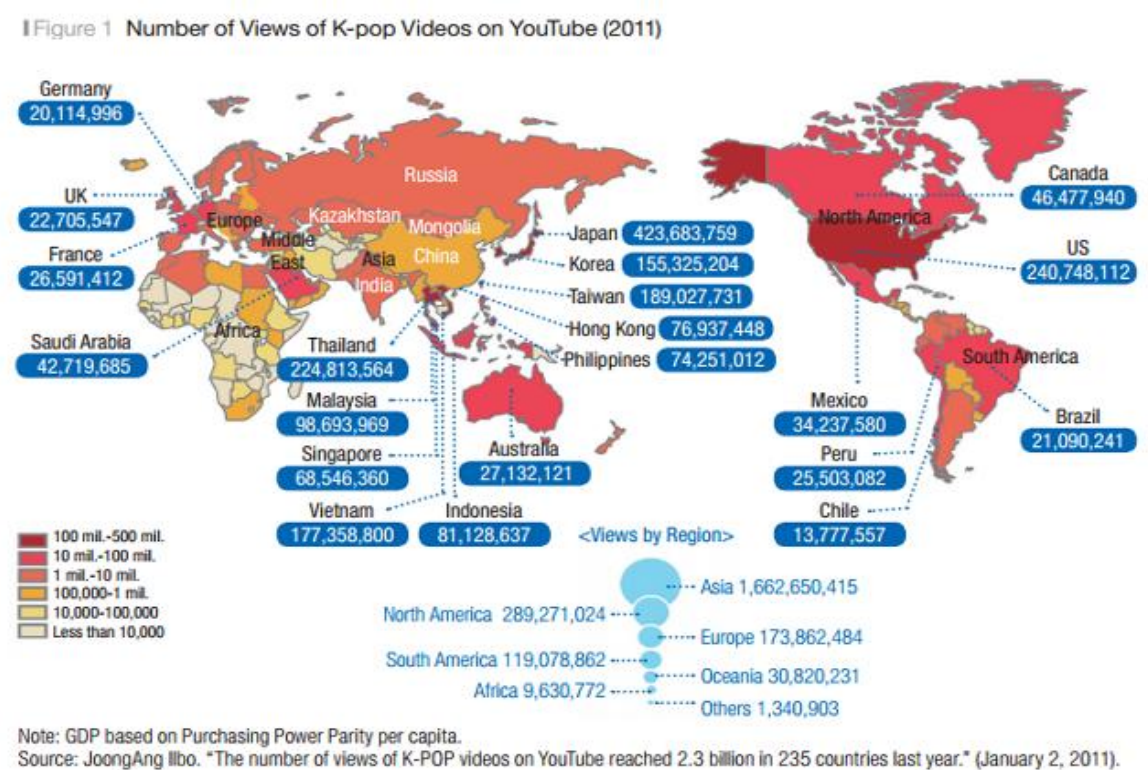

Figure 1. Number of Views of K-Pop Videos on Youtube in 2011 (Seo 2013)

SM Entertainment itself started a small company which was established by a former pop singer, Lee Sooman. It has been growing bigger since the explosive success of its first-generation idols, namely H.O.T, S.E.S, and Shinhwa. It introduced a distinct traineeship model in Korean music industry which is now followed by the rest of the entertainment agencies in South Korea. Its idol groups also dominate the music industry, as proven by the number of album sales and the 60 percent of market share SM Entertainment currently has (Messerlin \& Shin 2013; Yonhap News 2016a). Over the years, it has turned into a giant corporation who is leading the Hallyu Wave. It still employs the traditional traineeship, but it expands the audition globally and starts debuting idols originated from China and Japan. It also manages to reap of tremendous profit. In 2012, their net income jumped 82 percent in revenue to USD 225 million and boasted a market capitalization of USD 660 million, the biggest among other entertainment companies in Korea (Forbes 2013; JPop Asia 2013b).

\section{The Hallyu Wave}

As the Hallyu wave expands, there are a lot of researches regarding this phenomenon from various fields of study, such as business, finance, cultural studies, tourism, etc. Previous studies regarding Hallyu Wave also varied from Korean pop music (Lie 2012; Oh \& Park 2012; Kim 2012); Korean drama (Yang 2012; Lee, Scott, \& Kim 2008; Kim, et al. 
2007; Chuang \& Lee 2012); Korean products (Lita \& Cho 2012; Huang, et al. 2008). Lie (2012) generally analyzed the history of Korean music and the Korean culture embedded-ness in Korean pop music which has become one of the main tools in expanding Hallyu Wave. He then concluded that Hallyu Wave is merely one of the brands that Korean government exports to foreign countries (Lie 2012). In line with Lie (2012), Oh \& Park (2012) concluded that Hallyu is not a business which is distinctively different from other Korean export industry. Kim (2012) found out that many business sections such as such as wholesale-retail, restaurant, information service, clothes, ornaments, and cosmetics are greatly affected by K-Pop's success.

Hallyu Wave has also left tremendous profit on South Korean economy and the music industry has also become a large and highly profitable industry in South Korea. With the group of idols as their main products, companies could reap billions of profits by selling their physical albums, digital songs, and merchandises. They also made several million dollar contracts with MNEs like Google and Youtube to market their products (Oh and Park 2012). Korean pop's revenue has become a strategic asset and has recorded 5 trillion won of economic effects in 2010 (Korea Foundation for International Culture Exchange in Seo 2013).Total income gained from the Hallyu Wave is estimated to be over $\$ 50$ billion dollars in 2020 (Maeil Business Newspaper in Kim 2012). Moreover, the music industry export (mostly in terms of CD sales) also recorded an astonishing number of more than 100\% rise during 2008-2011 and averagely 36.4 percent per year (Messerlin \& Shin 2013). K-Pop market share in world music also increased from 33rd in 2005 to 11th in 2012 (International Federation of the Phonographic Industry in Kim 2012). In short, Howard (2014 as in Negus 2015) described K-pop aptly as the "McDonaldization of the music business"

Therefore, there are many other researchs trying to analyze the Korean pop (particularly about its fandom as the niche market) and why this particular music has become tremendously popular. Cha and Kim (2011) tried to analyzed the virtual communication channels between Korean pop fans in Europe and SM Entertainment. While Ryu (2011 in Oh \& Park 2012) conducted a research on korean pop fans in France to find out how they got to know K-pop and their dedication to form a K-pop community in France. Meanwhile for the international business side, Kim (2012) analyzed korean pop revenue model;Oh and Park (2012) examined how the business model for Korean pop has shifted from B2C basis to B2B, making SM Entertainment as one of their main study cases; and Jin (2012 in Oh \& Park 2012) tried to examine the impact of Hallyu in the digital era to creative industry. Based on the literature review, I shall try to depict what kind of business strategies used by SM Entertainment to grow from a small company to a global corporation; as 
well as its strategies to compete and obtain profits in the increasingly saturated market in Korean music scene.

Korean Wave (Hallyu Wave) started largely because of the Korean entertainment industry and the popularity of Korean drama and Korean pop (Urban Dictionary). It started around late 9os with the booming of an extremely popular Korean drama (Winter Sonata) and from music industry, the birth of new generation of K-Pop music through Seo Taiji and Boys. After Seo Taiji and Boys became widely popular, entertainment agencies started being established in South Korea and looked for teenagers to be groomed as superstars. One of Seo Taiji members itself, Yang Hyunsuk, established his own entertainment agency called YG Entertainment which has become one of the biggest agency in Korean entertainment industry today.

SM Entertainment, as the case study in this article itself, can be said as one of the core players in the Hallyu Wave. In 1995, Lee Sooman, a popular singer and songwriter in the 1970s, established SM Entertainment and employed traineeship method for its potential stars (Jung \& Shim 2014). Then, first ever popular K-pop idol group, H.O.T (High-five of Teenagers), was produced by SM Entertainment in 1996 and became explosively popular. They were the pioneer of Hallyu Wave and created an unprecedented fan-culture (such as having official fancolor and fan-club name, giving luxurious gifts to idols, and donating rice wreaths) which is preserved until now. After the immense success of H.O.T, SM Entertainment produced a string of idol groups for many generations of Korean Pop; such as S.E.S(1997), Shinhwa (1998), DBSK (2003), CSJH The Grace (2005), Super Junior (2005), Girls Generation (2007), Shinee (2008), EXO (2012), Red Velvet (2014), and NCT (2015). With such list of idol groups (albeit some of them either left the company or disbanded), SM Entertainment becomes one of the biggest entertainment companies in South Korea. In 2012, the label earned KRW 168,560,155,987 ( $\$ 155.1$ million USD) in revenue, a 53.5\% increase from the year before and accounted net profit totaled KRW 37,177,156,185 ( $\$ 34.2$ million USD) (Jpop Asia 2013b). In 2016, it reported a $139.8 \%$ rise of profits for its consolidated operations (in both music and drama fields), accounted for USD 7.7 million only for a quarter part of the year (Hong 2016). In order to gain such profits, SM Entertainment employs three strategies, namely traineeship, B2C (business-to-consumer) strategy, and B2B (business-to-business).

\section{Traineeship Strategy}

The first strategy is traineeship system.Different from American or Western music industry which gives cash in advance for the singers in the hope for return of investment later, Korean pop music industry 
prepared its idol groups as the "final products" painstakingly in a traineeship system.This traineeship system is employed to ensure their "final products" could be sold well and fit the market demands. This system is maintained from H.O.T era until now; while adding the practice of localization and globalization for overseas market (Jung \& Shim 2014); namely by recruiting foreign trainees and incorporating foreign language lessons in the training package. SM Entertainment holdsan audition every year, though some were scouted on the streets. After they passed the audition, they would be trainees. Korean pop trainees usually receive a regimented, structured, and strict training after they were selected. The training includes singing, dancing, acting, learning languages, practicinginterview skills, and many more (Messerlin \& Shin 2013). Each of them must also train their special individual talent, such as break-dancing, tumbling, or voice mimicry. Strict dietary control to facial to cosmetics surgery are also included in the training packages which are all paid by the agencies (Song 2011 in Oh \& Park 2012). Their training period will be varied from several months to several years. All of the living expenses during training period are paid by the agencies, including food, dormitory, clothes, expert tutors' fee, and all training classes (Kpopalypse 2014). It also must be noted that there was never a guarantee to debut once someone signed to become a trainee in a company.

Brian Joo, a member of Fly to the Sky (R\&B duo who debuted under SM Entertainment in 1999 and left in 2004) once retold his training days in SM Entertainment, "My day would start at $7 \mathrm{am}$. We did dance with two different choreographers, vocal training, how to speak to the camera, how to approach people." (Forbes 2013). Oh \& Park (2012) cited that Koike Kazuhiko, CEO of Universal music, commented that the Korean idols have "professional perfectionism in music, vocal, dancing, visual presentation, and entertainment; and this kind of perfectionism doesn't exist in Japan” (Jung 2010 in Oh \& Park 2012).

Reflecting on the extent of the training, it can be assumed that the expense of grooming a singer in Korean pop industry is nowhere cheap. Lee Sooman, SM Entertainment founder, claimed that his company spent USD 3 million won only to train BoA, SM's solo singer who made an astonishing success in Japan (Kim 2012 in Oh \& Park 2012). To make an idol group, of course it will take much more, as in a group there will be at least 4 or 5 members. The estimated cost to groom an idol group is USD 400,000 (Financial Review 2012). In SM Entertainment, 20 to 30 trainees costed approximately USD 100,000 a year and to debut, they usually offered a contract which lasts as long as 15 years (Bevan2012).A trainee can be dropped by their company at any point in time if they are not good enough for the company (seoulbeats.com) even though they already signed a contract with the company (Leung 2012). For popular group like SNSD, it took around 2.5-5 million USD to train each of nine 
members, including cost of living and housing expenses as well as the hiring of choreographers, trainers, voice coaches, dance teachers, and language tutors (Leung 2012).

Prior to debut a group, the company would also decide on the group's image and members' personalities (Jung \& Shim 2014). H.O.T, for example, was debuted with a mythical and mysterious image. Later in 2012, one of its former member, Moon Hee Jun disclosed that due to the mysterious and mythical image, the members couldn't even go to the toilet on the broadcasting station because it would ruin their image (Strong Heart 2012). An idol group member is not allowed to have a say in their choice of music nor image.

The whole business emphasized on business strategy of the mass production of idol groups who posses multinational and transitional skill, yet with low price (Oh \& Park 2012). Due to the amount of investment a company spent on the trainees, once the trainee debuted, he or she would have to pay everything back to the company by working as an idol. In the korean pop business model, the singer actually receive the most minimum payment. Most of the payment of their work would go to the company, the amount would depend on their contract but the ratio would be around 70:30 or even 90:10 (Kpopalypse 2014). If the idol groups do not do well, they have to work continuously until they could gain some profits in order to get paid. All K-Pop groups must work almost all day long on daily basis. If they are popular, they could appear everywhere and would only be able to sleep during the journey between their schedules (Leung 2012). For example, Girls' Generation, who appeared in the three live shows aired on TV on Dec. 31st, 2011, in Korea and Japan, had to fly back to back from Korea to Japan in a short period (Leung 2012). Therefore, BBC News (2011 in Leung 2012) pointed out "some of K-Pop's biggest success stories were built on the back of socalled slave contracts, which tied its trainee-stars into long exclusive deals, with little control or financial reward." Despite questions on its business ethic and human right violation (TIME 2002; Jpop Asia 2014), this kind of system has been pertaining and succeeding for more than two decades now.

\section{B2C Strategy}

The second strategy is maximizing the $\mathrm{B} 2 \mathrm{C}$ (business-to-consumers) strategy, because Korean music industry was mostly based on fanservice industry. The industry sells physical albums, digital songs, official merchandises, concerts, product endorsements, and even official fanclubs registration. Korean music industry, especially SM Entertainment, has successfully established its own niche market. Targeting mostly on fandoms separates them from other music 
industries. Compare to another music fandom, korean pop fandom are a bit distinctive in nature, as well. David Jennings (in Leung 2012) writes, "perhaps most importantly for a community of music fans, the extended period of doing things together gives a sense of collective identity linked to their favorite bands". Korean pop fandom culture started from H.O.T with their Club H.O.T. Their sense of loyalty and collective identity in korean pop fandom culture is relatively strong, so each person could only pick one fandom to belong to; consequently, they would only buy the products related to their own favorites. SM Entertainments is known for building this niche market well, as put by The Guardian below:

SME even has its own merchandise store in Seoul. The SM Entertainment building...contains a coffee shop, luxury restaurant, a section where you can take pictures that look like you're sitting with the SME stars, and a store for SME artist memorabilia. Though 55\% of Korean music sales are digital, [SM Entertainment] makes sure that physical CDs are attractive enough for the fans to splurge on them as well. It doesn't release records in ordinary CD cases; they're all in glossy luxury packaging. They're often released in up to five different packages--and the fans buy them all. (The Guardian 2011)

With K-Pop become more popular abroad, there are many sites, forums, blogs, news portals opened anywhere in the world. K-Pop news blogs, band tribute videos on YouTube, online video streaming sites, and other fan-produced content are not just reflections of K-Pop's popularity around the world but they also help driving the production and popularity machine (Leung 2012). K-Pop fans have created an environment of "grassroots convergence," in which audiences increasingly influence the production, distribution, and reception of media (Leung 2012).

The nature of the niche market has helped the companies to shape their marketing strategy. For example, in selling the supposedly demise physical albums. In digital era, releasing physical album has less appeal. Yet for K-pop industry, it even grew by a whopping 25.6 percent in 2008 , in 2009 by 10.4 percent, in 2010 by 12.3 percent and in 2011 by 6.4 percent (digitalmusicnews.com). K-pop industry boost physical album sale by using smart and luxurious packaging method. It put the CD inside a beautifully wrapped case or even a box and put CD, photobooks, postcards, posters inside to attract fans to buy. Some online stores even sell it in higher price by putting signatures from idol groups as a bonus.Physical CD sales specifically target the niche market, as it is usually used as the measurement of 'fan status' (Messerlin \& Shin 2013). Therefore, to boost the sales, SM Entertainment often released different cover version of an album. For example, SM Entertainment released 10 
different covers for SNSD's "I Got a Boy" album in 2012; for EXO, they released two versions of albums in Korean and Chinese as a part of their market penetration strategy in China. The total sales for all EXO's 'XOXO' album version even reached one million copies in 2013 (Mwave 2013) and their latest album, EX'ACT, recorded more than 2 million copies in 2016 (Yonhap News 2016a). SM Entertainment could cash in CDs worth 3 billion won in 2011 (The Economist 2012).

Meanwhile, for digital service, the subscription-based services are extremely popular and cheap. This service helped driving digital music sales to 430 billion won in 2011 (Economist 2012). In 2013, the consumers can buy 150-200 songs in Korea while the consumers overseas would only get 10-15 songs with the same amount of money (Messerlin and Shin 2013). Digital market is also boosted by the music programs' system in South Korea. After releasing an album, the company puts an idol group through a series of music stage promotion in Korean TV stations to win awards on these shows. The winner determined by the number of sales (digital, physical, and the number views on Youtube). According to Messerlin and Shin's (2013) research, SM Entertainment conquered 62.1 percent market share for physical sales in 2013. Furthermore, at the same year, it positioned in \#7 for the number of monthly download (6.6\% of the market share) and \#6 for monthly streaming ( $6.6 \%$ of the market share).

However, the company and artist still would not gain much from this. Under the subscription deals, they only collected 30 won per track which have to be split between writer, label, and artist. This caused SM Entertainment CEO, Kim Young Min complained that even 1 million downloads could not cover the cost of making a music video (Oh \& Park 2012; Economist 2012). This fact has led SM to expand to B2B (business-to-business) strategy, the third strategy.

\section{B2B Strategy}

Even though Korean music industry was mostly based on fan-service industry, as Oh and Park (2012) argued in their paper, it has gradually embraced B2B (business-to-business) model. In dealing with globalization, SM Entertainment has also built a cooperation with famous composers and choreographers around the world (Song 2012 in Jung \& Shim, 2014; Oh \& Park 2012; Negus, 2015). For example, 'Genie' by SNSD was written by a Korean songwriter, composed by Norwegian company, and choreographed by a Japanese Dancer (Yun 2011 in Jung \& Shim 2014). These efforts are aimed to broaden and globalized the Kpop market, especially because its fans are currently spread around the world. 
Furthermore, SM Entertainment made a contract with multinational companies like Google or Youtube to market their products (Oh \& Park 2012). Youtube provides a convenient mean for content distribution, as everyone with internet could access it freely. In particular, there is also a tendency of declining market for physical copies and rampant piracy all over the world. Social media and Youtube made it possible for listeners to enjoy unbundled music they could not get from CDs. With the emergence of social media and internet music shops like iTunes, unbundling or selling music piece by piece is now a trend (Elberse 2010 in Oh \& Park 2012). Online portals made it possible for companies and musicians to sell their music legally and prevent piracy all over the world. As shown by Figure 1 above, the viewers of K-pop contents on Youtube are mostly not from South Korea. SM Entertainment official Youtube channel (youtube.com/smtown) currently has more than 9 million subscribers and the most popular video ("I Got a Boy" by SNSD) got more than 179 million views. In 2013, its official channel recorded $202,716,382$ hits for Youtube views which amounted to 11.3 percent of the overall market share (Messerlin \& Shin, 2013). The importance of Youtube views is also enhanced by incorporating the number of views for music chart ranking; thus, the K-pop consumption via Youtube has also reached the main niche market. For each view of one video, the viewers consume the Youtube advertisement played before the actual content. In such way, Youtube profited from the number advertisement and shared the profits with SM and the advertisement.Therefore, from its official Youtube channel, SM Entertainment managed to reap 81 percent of royalty income from overseas viewers in 2010 (Oh \& Park 2012).

In addition to partnership with Youtube and Google, SM Entertainment also cooperates with some overseas music labels as their distributors. It allied with Avex Group, Sony Music Entertainment in Japan, and EMI Music Japan to penetrate Japan market. The immense success of BoA and TVXQ in early and mid-2000s in Japan market proved that that cooperation succeeded.Furthermore, in 2016, SM Entertainment expands partnership with non-music partners, such as Shinsegae, eMart, and Alibaba (all of them are from retail industries), to sell a package bundling of their artists and the retail products (Yonhap News 2016b). The bundling sells packages of manufactured food with the images of their artists, such as "Girls Generation popcorn" and "Super Junior ramen". This strategy aims to attract more niche consumers to buy and travel to Korea. In accordance with its aim to be more "global", SM Entertainment also began selling 870,000 shares (35.5 billion won in value)out of the total 20,885,633 shares to Chinese Alibaba, even though it previously limited its door to foreign investment (Yonhap News 2016b).

SM Entertainment is the champion and industry leader of this new B2B business model for the K-pop industry, its total B2B revenue accounted 
for $80 \%$ of total sales in 2010 (Oh \& Park 2012). In the first quarter of 2016, SM also recorded $71 \%$ rise in the business sector (USD 36.9 million) based on its artists' portfolios in music, commercials, and concerts (Hong, 2016). Those portfolios include the product endorsement and appearance fees for SM artists.

\section{Conclusion}

Korean pop business model (particularly SM Entertainment) encompasses some strategies of which other companies in business field could learn from. Firstly, they employ a distinct system of traineeship which ensures the quality of the "final products." Secondly, they successfully establish the niche market to market their products. In addition, they also build a system to keep the consumers buying the products, such as by incorporating digital, physical, and Youtube views in music programs' charts. As a result, this B2C strategy helps SM gaining a huge share in the market and reaping tremendous profits, even in the dying physical CD market. Thirdly, as K-Pop and the company itself grow more globalized, SM Entertainment realizes the needs to expand its business and not relying solely on the B2C strategy. Through various partnerships and cooperation with the multinational and/or overseas companies, SM Entertainment starts being a truly global company. Besides, it also unhesitatingly integrates online platforms, such as Youtube and social media, into its strategy in reaching global consumers. Those strategies result in the multiplying of profits and revenue, as well as growing consumer market.

\section{References}

\section{Journal and Online Journal}

Chuang, Lisa M., \& Lee, Hye Eun, 2012. "Korean wave: enjoyment factors of korean dramas in the U.S". International Journal of Intercultural Relations, 37: 594-604.

Huang, Yu-An., Phau, Ian., Lin, Chad., Chung, Hsien-Jui., \& Lin, Koong Hao-Chiang, 2008. "Allocentrism and consumer ethnocentrism: the effects of social identity on purchase intention". Social Behavior and Personality, 36(8): 1097-1110.

Jung, Sun and Shim, Doobo. 2014. "Social distribution: K-pop fan practices in Indonesia and the 'Gangnam Style' phenomenon". International Journal of Cultural Studies, 17(5): 485-501. 
Jung, Sun, 2012. "Fan activism, cybervigilantism, and Othering mechanisms in K-pop fandom". Transformative Works and Cultures (TWC). [online] available at http://journal.transformativeworks.org/index.php/twc/article/view/ 300/287 [accessed on 1 December 2016]

Kim, S.S., Agrusa, J., Lee, Heesung., \& Chon, Kaye, 2007. "Effects of korean television dramas on the flow of Japanese tourists". Tourism Management, 28: 1340-1353.

Kim, Sang Yeob, 2012. "Investigation on the Management Status of KPop Revenue Model and Finding Ways for Improvement". International Journal of Trade, Economics and Finance,3(5).

Lee, Soojin., Scott, David., \& Kim, Hyounggon, 2008. "Celebrity fan involvement and destinations perceptions". Annals of Tourism Research, 35(33): 809-832.

Lee, Sue Jin, 2011. "The Korean wave: the Seoul of Asia". The Elon Journal of Undergraduate Research in Communications, 2(1): 85-93

Leung, Sarah, 2012. "Catching the K-Pop Wave: Globality in the Production, Distribution, and Consumption of South Korean Popular Music". Senior Capstone Projects, 149.

Lie, John. 2012. "What is the $\mathrm{K}$ in the K-Pop? South Korean Popular Music, the Culture Industry, and National Identity". KOREA OBSERVER, 43 (3): 339-363

Lita, Rahmiati., \& Cho, Yoon C, 2012. "The influence of media on attitudinal And Behavioral Changes: Acceptance Of Culture And Products". International Business \& Economics Research Journal, 11(12).

Messerlin, Patrick and Shin, Wonkyu, 2013. "The K-pop Wave: An Economic Analysis" [online] available at http://gem.sciencespo.fr/content/publications/pdf/MesserlinShin_Kpop01072013.pdf[accessed on 1 December 2016]

Negus, Keith, 2015. "The South Korean Music Industry: A Literature Review”. CREATe Working Paper, 2015/12.

Oh, Ingyu and GilSung, Park, 2012. "From B2C to B2B: Selling Korean Pop Music in the Age of New Social Media”. KOREA OBSERVER, 43(3): 365-397.

Ravina, M, 2010. "Introduction: the conceptualizing the korean wave: southeast review of asian studies". Magazine Back Issues \& Reference Articles.

Shim, D and Noh, K.W, 2012. "YouTube and Girls' Generation fandom". Journal of the Korea Contents Association, 12(1): 125-137.

Yang, Jong Hoe. 2012. "The Korean wave (hallyu) in East Asia: a comparison of chinese, Japanese, and Taiwanese audiences who watch korean TV dramas". Development and Society, 41(1): 103-147. 


\section{Online Articles}

Bevan, David, 2012. "Seoul Trained: Inside Korea's Pop Factory",SPIN. [online] available athttp://www.spin.com/articles/seoul-trainedinside-koreas-pop-factory/[accessed on 2 December 2016]

Financial Review, 2012. "K-Pop: X Factor on steroids" [online] available at

http://www.afr.com/p/national/pop_factor_on_steroids_sL3eUJyS gQZ6jPvE76jslO[accessed on 3November 2016]

Hong, C. 2016. "SM Entertainment Records Highest First Quarter Profit in Its History",Soompi News [online] available athttps://www.soompi.com/2016/05/12/sm-entertainment-recordshighest-first-quarter-profits-in-its-history/[accessed on 15 December 2016]

Jpop Asia, 2013a. "PSY's "Gentleman" MV Viewed Over 22 Million Times In First Day, Record For Most Views In A Day" [online] available athttp://www.jpopasia.com/news/psys-gentleman-mvviewed-over-22-million-times-in-first-day-record-for-most-views-ina-day::13549.html [accessed on 1 December 2016]

Jpop Asia, 2013b. "SM Entertainment, YG Entertainment Reveal 2012 Earnings Report" [online] available athttp://www.jpopasia.com/news/sm-entertainment-ygentertainment-reveal-2012-earnings-report::13120.html[accessed on 1 November 2016]

JpopAsia, 2014. "Kris Claims SM Entertainment Violated Basic Human Rights" [online] available at from http://www.jpopasia.com/news/kris-claims-sm-entertainmentviolated-basic-human-rights::16301.html[accessed on 11 December 2016]

Korea Creative Content Agency (KOCCA), 2014. "Introduction" [online] available athttp://eng.kocca.kr/en/contents.do?menuNo=201433 [accessed on 1 November 2016]

Kpopalypse, 2014. "Chocolate Love-Marketing 101 for deluded K-pop fans" [online] available at http://kpopalypse.wordpress.com/2014/o1/o7/chocolate-lovemarketing-101-for-deluded-k-pop-fans/[accessed on 11 November 2016]

Lindvall, Helienne, 2011. "K-pop: how South Korea turned round its music scene", The Guardian [online] available at http://www.guardian.co.uk/media/ organgrinder/2011/apr/20/kpop-south-korea-music-market [accessed on 1 December 2016]

Lindvall, Helienne, 2013. "How K-Pop \& J-Pop Are Saving Physical Music Sales" [online] available at http://www.digitalmusicnews.com/permalink/2013/20130410kpopj pop, [accessed on 6 December 2016] 
Mwave, 2013. "EXO's Album 'XOXO' Sells Over a Million Copies" [online] available at http://mwave.interest.me/enewsworld/en/article/54504/exo-firstalbum-becomes-a-million-seller[accessed on 1 November 2016]

Salmon, Andrew, 2013. "Korea's S.M. Entertainment: The Company That Created K-Pop. Forbes Asia" [online] available athttp://www.forbes.com/sites/forbesasia/2013/07/31/koreas-s-mentertainment-the-company-that-created-k-pop/ [accessed on 1 December 2016]

Seo, Min-Soo, 2013. "Lessons from K-pop's Global Success; Applying Kpop success strategy to business" [online] available at http://www.korea-marketing.com/lessons-from-k-pops-globalsuccess/

Seoulbeats, 2012a. "The Book Finally Closes on the JYJ/SM Conflict" [online] available at http://seoulbeats.com/2012/12/the-book-finallycloses-on-the-jyjsm-conflict/ [accessed on 15 November 2016]

Seoulbeats, 2012b. "The Road to K-pop Stardom: Training" [online] available athttp://seoulbeats.com/2012/02/the-road-to-k-popstardom-training/ [accessed on 1 December 2016]

The Economist. 2012. "South Korea's music industry; Top of the K-pops" [online] available at from http://www.economist.com/node/21560605 [accessed on 8 December 2016]

TIME Magazine. 2002. "Flying Too High?" available athttp://content.time.com/time/world/article/o,8599,2056115,oo.ht $\mathrm{ml}$ [accessed on 1 November 2016]

Yonhap News, 2016a. "EXO boasts strong album sales in 2016" [online] available

athttp://english.yonhapnews.co.kr/news/2016/12/29/020000000o AEN20161229002500315.html[accessed on 30 December 2016]

Yonhap News, 2016b. "Star agencies expand portfolio outside K-pop" [online] available at http://english.yonhapnews.co.kr/news/2016/o3/11/92/02000000o oAEN2016 0311008400315F.html [accessed on 30 December 2016]

\section{Others}

SBS Strong Heart, 2012. "StrongHeart [liveshow]" South Korea: Seoul Broadcasting Station. 